\title{
Influence of Red Blood Cell Storage Time on Clinical Course and Cytokine Profile in Septic Shock Patients
}

\author{
Pia Lebiedz ${ }^{\mathrm{a}} \quad$ Sabina Glasmeyer ${ }^{\mathrm{b}} \quad$ Ekkehard Hilker $^{\mathrm{a}} \quad$ Akin Yilmaz-Neuhaus $^{\mathrm{a}}$ \\ Theodoros Karaboutas $^{a}$ Holger Reinecke $^{a}$ Walter Sibrowski ${ }^{b}$ Jerzy-Roch Nofer ${ }^{c, d}$ \\ a Department of Cardiology and Angiology, \\ ${ }^{\mathrm{b}}$ Institute of Transfusion Medicine and Transplantation Immunology, \\ ${ }^{c}$ Center for Laboratory Medicine, University Hospital Münster, Münster, Germany \\ ${ }^{\mathrm{d}}$ Department of Medicine, Endocrinology, Metabolism and Geriatrics, University of Modena and Reggio Emilia, Modena, Italy
}

\section{Keywords \\ Erythrocyte transfusion - Septic shock . \\ Hemodynamic parameters · Inflammation markers}

\section{Summary}

Background: Previous investigations have suggested beneficial effects of fresh versus stored red blood cell transfusion in critically ill patients. The present study investigates the effects of red blood cell storage time on the clinical course and hemodynamic and laboratory parameters in patients with septic shock. Patients and Methods: 18 patients with septic shock received 2 erythrocyte units stored for $\leq 7$ days $(n=8)$ or $>7$ days $(n=10)$. The sequential organ failure assessment (SOFA) score was calculated for 7 days. Hemodynamic parameters (cardiac index, extravascular lung water) were determined using transpulmonary thermodilution. Laboratory parameters (lactate, base excess, C-reactive protein, procalcitonin, IL- $1 \beta$, IL-6, TNF- $\alpha$, sVCAM-1, sICAM1) were monitored before and 1, 3, 6, 12, 24, and $48 \mathrm{~h}$ after transfusion. The Mann-Whitney- $U$ test and Neumann test were used for group comparison and trend assessment, respectively. Results: We failed to observe significant differences with respect to SOFA scores between patients receiving fresh or stored erythrocytes. However, a significant trend towards an improvement in the SOFA score was found in the group receiving fresh erythrocytes $(p<0.01)$. No significant differences in hemodynamic or laboratory parameters were found between both groups. Conclusion: While the present findings do not provide clear-cut evidence supporting beneficial effects of fresh red blood cells in septic shock, they warrant larger randomized studies to confirm or refute such effects.

\author{
Schlüsselwörter \\ Bluttransfusion · Septischer Schock · Hämodynamische \\ Parameter . Proinflammatorische Zytokine
}

\section{Zusammenfassung}

Hintergrund: In vorangegangenen Studien wurde ein positiver Effekt von frischen verglichen mit gelagerten Erythrozytenkonzentraten (EK) auf den klinischen Verlauf kritisch kranker Patienten gezeigt. Die vorliegende Studie untersucht den Effekt der EK-Lagerungsdauer auf den klinischen Verlauf sowie die hämodynamischen und Laborparameter im septischen Schock. Patienten und Methoden: 18 Patienten im schweren septischen Schock erhielten jeweils 2 EKs mit einer Lagerungsdauer von $\leq 7$ Tagen $(n=8)$ oder $>7$ Tagen ( $n=10$ ). Der Sequential Organ Failure Assessment (SOFA)-Score wurde über 7 Tage registriert. Hämodynamische Parameter (kardialer Index, extravaskuläres Lungenwasser) wurden mittels transpulmonaler Thermodilution bestimmt. Laktat, Basenabweichung, C-reactives Protein, Procalcitonin, IL-1 $\beta$, IL-6, TNF- $\alpha$, sVCAM-1 und sICAM-1 wurden vor und an Stunde 1, 3, 6, 12, 24 und 48 nach Transfusion bestimmt. Der Mann-Whitney-U-Test und NeumannTest wurden zur statistischen Analyse der Unterschiede zwischen den Gruppen bzw. zur Trendanalyse eingesetzt. Ergebnisse: Zwischen den Patientengruppen, die frische bzw. gelagerte Konzentrate erhielten, konnten keine Unterschiede bezüglich des SOFA-Scores beobachtet werden. Trotzdem zeigte die Trendanalyse innerhalb der einzelnen Gruppen, dass Patienten, die frische EKs erhielten, einen signifikanten Trend zur Verbesserung des SOFA-Scores $(p<$ $0,01)$ hatten. Dieser Trend zu einem besseren klinischen Verlauf ließ sich jedoch nicht mit signifikanten Unterschieden in den hämodynamischen oder klinischen Parametern in Verbindung bringen. Schlussfolgerung: Die vorliegenden Ergebnisse belegen keinen sicheren Vorteil einer Transfusion von frischen statt gelagerten EKs im septischen Schock. Der positive Trend im klinischen Verlauf sollte jedoch in größeren randomisierten Studien überprüft werden. (c) 2012 S. Karger GmbH, Freiburg

$1660-3796 / 12 / 0394-0271 \$ 38.00 / 0$

Accessible online at:

www.karger.com/tm
Dr. med. Pia Lebiedz

Department of Cardiology and Angiology

University Hospital Münste

Albert-Schweitzer-Str. 33, 48149 Münster, German

Tel.+49 251 83-47641, Fax -46190

pia.lebiedz@ukmuenster.de 


\section{Introduction}

Septic shock, systemic inflammatory response syndrome (SIRS), and multi-organ dysfunction syndrome (MODS) are characterized by disturbances in microcirculation and tissue oxygen utilization [1]. Therefore, optimizing the oxygen transport capacity in patients with septic shock remains an essential part of therapy, and red cell transfusion to maintain an adequate hemoglobin $(\mathrm{Hb})$ level or central venous oxygen saturation is recommended by international guidelines [2, 3]. Some studies, however, challenge the red blood cell transfusion in sepsis in principle, because the oxygen utilization itself does not increase after transfusion $[4,5]$ and because microcirculation in sepsis does not generally improve after red blood cell administration [6]. Hence, the correct approach regarding the transfusion strategy in patients with sepsis remains controversial [7]. It has been hypothesized that erythrocyte function diminishes with prolonged storage time of packed red blood cells and that red cells undergo biochemical changes during storage characterized by an impeded capacity to transport oxygen $[8,9]$. This effect, termed 'storage lesion', has been noted in several studies. For instance, Marik and Sibbald [5] observed an increase in splanchnic ischemia after transfusion of red blood cells stored for more than 15 days in septic patients, and attributed this effect to microcirculatory occlusion due to reduced deformability and altered adhesion properties of older erythrocytes. In addition, a correlation between mortality and storage time of transfused red blood cells was retrospectively reported by Purdy et al. [10]. These results are in agreement with other studies that demonstrated an association of red cell storage time with mortality and/or other adverse outcomes in postsurgical and trauma patients [11-15]. However, other studies found no significant differences in mortality and/or other outcomes in subjects treated with fresh or stored red blood cells [16-19]. The objective of the present work was to further assess potential benefits of fresh red blood cell transfusion, specifically in patients with septic shock. We conducted a prospective, observational, blinded study, and for the first time compared hemodynamic parameters as well as markers of inflammatory response and endothelial activation in addition to clinical parameters in septic patients receiving fresh or stored red blood cells.

\section{Material and Methods}

\section{Study Subjects}

This study was conducted according to the Declaration of Helsinki and was approved by the local ethical committee. Informed consent was obtained from direct relatives of all subjects recruited. The examined cohort comprised patients between 22 and 79 years of age with acute septic shock (symptoms lasting for less than $24 \mathrm{~h}$ ), $\mathrm{Hb}<9 \mathrm{~g} / \mathrm{dl}$ and hypotension (blood pressure $<90 \mathrm{~mm} \mathrm{Hg}$ ). Only patients that had been mechanically ventilated due to sepsis for less than $24 \mathrm{~h}$ before blood transfusion were considered in the study. In addition, patients had to meet at least 2 criteria of SIRS: temperature $>38$ or $<36{ }^{\circ} \mathrm{C}$, heart rate $>90 / \mathrm{min}$, respiratory frequency $>20 / \mathrm{min}, \mathrm{paCO}_{2}<32 \mathrm{~mm} \mathrm{Hg}$, or leukocyte count $>12,000$ or $<4,000 / \mu \mathrm{l}$. Exclusion criteria were surgery with cardiopulmonary bypass within the last $48 \mathrm{~h}$, active bleeding, clinically relevant hemolysis, serum ferritin $>1,000 \mathrm{mg} / \mathrm{dl}$, heart valve malfunction, status after gastrectomy, Child-Pugh class $\mathrm{C}$ liver cirrhosis, portal hypertension, or esophageal varices.

\section{Study Design}

This was a blinded, observational, non-randomized study. Consecutive patients fulfilling all criteria received 2 erythrocyte units of the same storage time (with a maximal difference of 1 day), if $\mathrm{Hb}$ was lower than $9.0 \mathrm{~g} /$ dl. Packed red blood cells aged 1-23 days were provided by the blood bank of the University Hospital of Münster and were leukocyte-reduced. The exact storage time was not known at the time of transfusion and was revealed after the observational period. Erythrocyte units were arbitrarily classified as fresh ( $\leq 7$ days old) or stored ( $>8$ days old). Accordingly, patients were divided into 2 groups receiving fresh or stored red blood cells. There was no blood bank policy to preferentially transfuse fresh red blood cells.

\section{Clinical and Laboratory Assessment}

Organ failure was assessed daily using the sequential organ failure assessment (SOFA) score for 7 days. Noradrenalin was used as vasopressor, and the required vasopressor dosages were registered at hours 0 (before transfusion) and 1, 3, 6, 12, 24, and 48 (after transfusion). All patients received a PiCCO catheter (Pulsion Medical Systems AG, Munich, Germany) for hemodynamic monitoring [20] and a central venous catheter. Hemodynamic parameters including cardiac index and extravascular lung water index were registered at hours $0,1,3,6,12,24$, and 48 . Basic laboratory parameters including arterial blood gas analysis, base excess, and lactate concentrations were registered at hours $0,1,3,6,12$, 24 , and 48. Serum concentrations of C-reactive protein (CRP) and procalcitonin (PCT) were determined 24 and $48 \mathrm{~h}$ after transfusion using Modular E (Roche, Mannheim, Germany) and Kryptor (Thermo, Berlin, Germany) automated laboratory analyzers, respectively. Cytokines including TNF- $\alpha$, IL-1 $\beta$ and IL-6, as well as markers of endothelial activation (soluble vascular cell adhesion molecule-1 (sVCAM-1) and soluble intercellular cell adhesion molecule-1 (sICAM-1)), were monitored before and 6 and $12 \mathrm{~h}$ after transfusion using ELISA kits (R and D Systems, Wiesbaden, Germany).

\section{Statistical Analysis}

Data are presented as mean \pm standard deviation (SD) or median and $1 \mathrm{st}$ and 3rd quartiles, as appropriate. Group comparison and trend assessment were performed using the Mann-Whitney-U test and Neumann test, respectively. Significance was assumed where $\mathrm{p}$ was $<0.05$.

\section{Results}

\section{Baseline Characteristics}

A total of 12 male and 6 female patients aged 22-79 years fulfilled the inclusion criteria. The median length of the stay in the intensive care units was 23 days, and the overall mortality was $61.1 \%$. The time from onset of sepsis to transfusion was $<24 \mathrm{~h}$ in all patients. No transfusion-related adverse reactions were observed during the study. The general characteristic of the analyzed patients are shown in table 1 . Patients in the first group received red blood cells stored $\leq 7$ days (mean 4.9 days); in the second group, the transfused erythrocyte units were stored for 8-23 days (mean 13.6 days). 
Table 1. Characteristics of the study patients

\begin{tabular}{|c|c|c|c|c|c|}
\hline Patients & Sex & Age, years & Admission diagnosis $^{\mathrm{a}}$ & $\begin{array}{l}\text { SOFA score } \\
\text { on admission }\end{array}$ & Survival \\
\hline \multicolumn{6}{|c|}{ Fresh red cell transfusion ( $\leq 7$ days) } \\
\hline 1 & M & 79 & AML & 16 & $\mathrm{~N}$ \\
\hline 2 & $\mathrm{M}$ & 63 & aplastic anemia & 18 & $\mathrm{~N}$ \\
\hline 3 & $\mathrm{~F}$ & 22 & toxic shock syndrome & 17 & $\mathrm{Y}$ \\
\hline 4 & M & 73 & ARDS/pneumonia & 15 & $\mathrm{Y}$ \\
\hline 5 & M & 59 & pneumonia & 16 & $\mathrm{Y}$ \\
\hline 6 & M & 32 & CML & 14 & $\mathrm{Y}$ \\
\hline 7 & M & 72 & multiple myeloma & 15 & $\mathrm{~N}$ \\
\hline 8 & $\mathrm{M}$ & 53 & myocardial infarction & 14 & $\mathrm{Y}$ \\
\hline Mean \pm SD & & $56.6 \pm 20.2$ & & $15.6 \pm 1.4$ & \\
\hline \multicolumn{6}{|c|}{ Stored red cell transfusion ( $>7$ days) } \\
\hline 1 & $\mathrm{~F}$ & 49 & phlegmasia cerulea dolens & 12 & $\mathrm{~N}$ \\
\hline 2 & $\mathrm{~F}$ & 79 & pneumonia & 10 & $\mathrm{Y}$ \\
\hline 3 & M & 56 & Crohn's disease & 17 & $\mathrm{Y}$ \\
\hline 4 & M & 53 & endocarditis & 14 & $\mathrm{~N}$ \\
\hline 5 & $\mathrm{M}$ & 27 & AML & 16 & $\mathrm{~N}$ \\
\hline 6 & $\mathrm{~F}$ & 37 & agranulocytosis & 17 & $\mathrm{~N}$ \\
\hline 7 & M & 35 & AML & 20 & $\mathrm{~N}$ \\
\hline 8 & $\mathrm{M}$ & 68 & pneumonia & 14 & $\mathrm{~N}$ \\
\hline 9 & $\mathrm{~F}$ & 44 & AML & 16 & $\mathrm{~N}$ \\
\hline 10 & $\mathrm{~F}$ & 59 & pancreatitis & 15 & $\mathrm{~N}$ \\
\hline Mean \pm SD & & $50.7 \pm 15.8$ & & $15.1 \pm 2.8$ & \\
\hline
\end{tabular}

Fig. 1. Changes in SOFA score during the study period in septic patients receiving fresh (closed symbols) or stored (open symbols) erythrocytes. No significant differences were noted between the groups. A significant trend towards SOFA score improvement was ob-

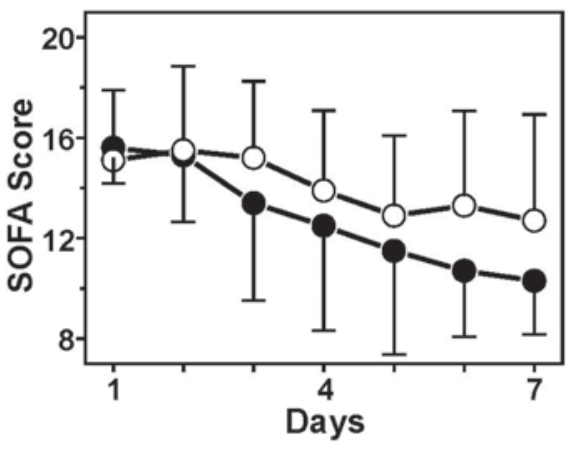
served in the group receiving fresh erythrocytes ( $p<0.01$, Neumann test).

\section{Clinical Course}

The design and size of the study did not allow analyzing differences in overall survival. The SOFA score reflecting the extent of organ failure was assessed in all patients before transfusion and followed-up for 7 days thereafter. The comparison of means between the groups receiving fresh or stored red blood cells revealed no significant differences. However, there was a significant trend towards SOFA score improvement in the group transfused with fresh erythrocytes (fig. 1), while no such tendency was observed in patients receiving stored erythrocytes.

\section{Physiological and Laboratory Variables}

Table 2 demonstrates changes in the hemodynamic and laboratory parameters measured in the groups receiving fresh and stored erythrocytes in the course of the study. There were no relevant differences at the time of randomization for any of the measured parameters. Red cell transfusion led to similar $\mathrm{Hb}$ changes in both examined groups.

Most patients presented with lactacidemia at study start, and lactate clearance during therapy did not differ significantly in both groups. Median base excess values normalized, and the need for vasopressors receded, in both groups in the course of the study. However, neither the base excess nor the serum lactate levels were significantly different in the groups receiving fresh or stored red blood cells. No differences between both groups were observed with regard to vasopressor doses.

Hemodynamic parameters examined by transpulmonary thermodilution included cardiac index and extravascular lung water index. None of these parameters was significantly different in patients obtaining fresh versus stored erythrocytes. Finally, the age of red blood cells transfused in septic shock failed to affect laboratory variables reflecting systemic inflammation such as CRP, PCT, and pro-inflammatory cytokines (IL-1, IL-6, TNF- $\alpha$ ), although there was considerable intra-individual variation, with improvement in some patients and deterioration in others. 


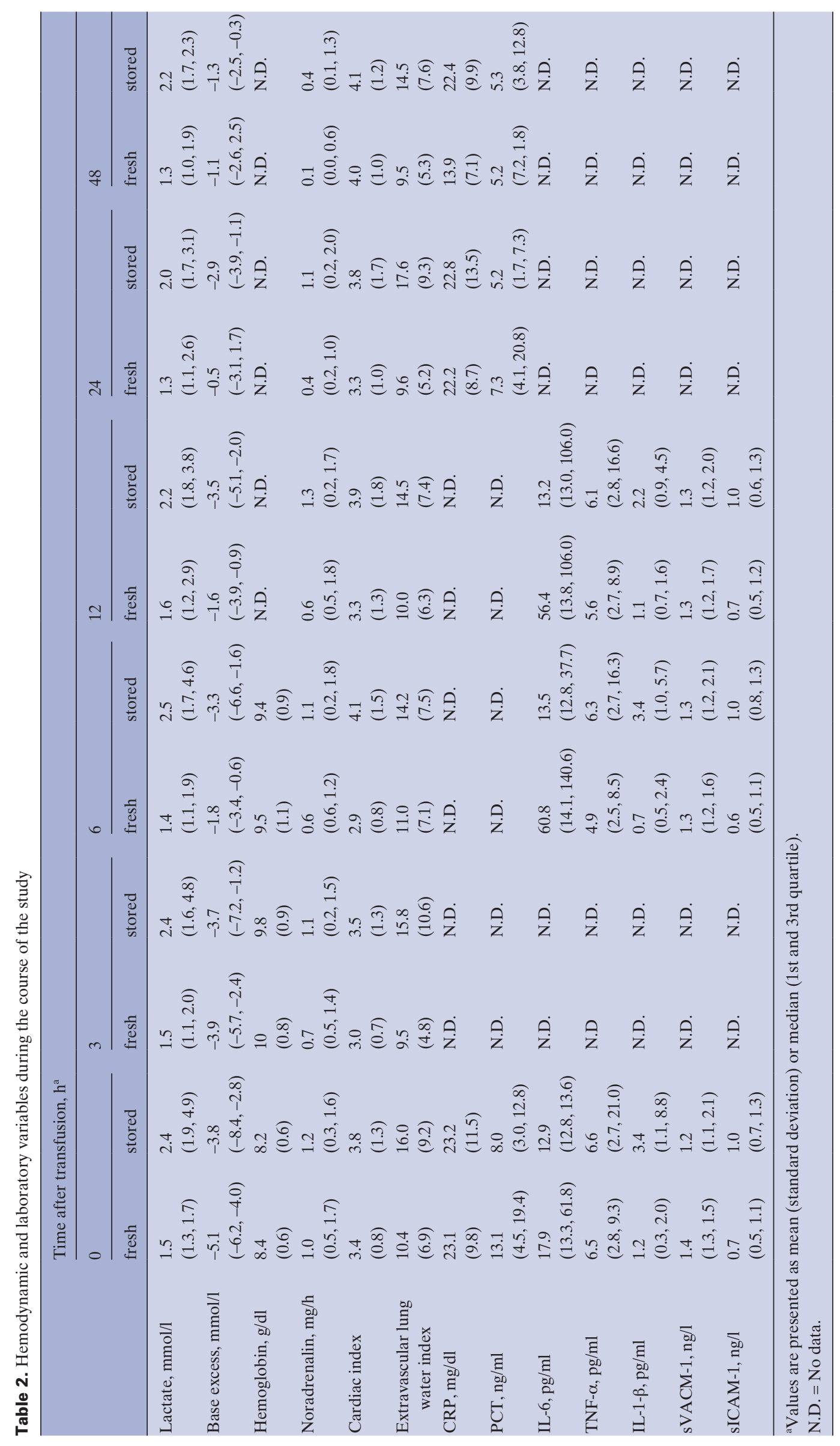


In addition, serum levels of sICAM-1 and sVCAM-1 that reflect the degree of endothelial activation were similar in the groups treated with fresh or stored red blood cells.

\section{Discussion}

The primary objective of the present work was to track the clinical course in patients with septic shock after fresh versus stored red blood cell transfusions. We failed to observe significant differences with respect to SOFA scores between patients transfused with fresh or stored erythrocytes. However, a significant trend towards an improvement in the SOFA score was found in the group receiving fresh red blood cells. To our knowledge, this is the first prospective study addressing the effects of the age of transfused erythrocytes on clinical outcome in the context of septic shock. However, the increased median age of packed red blood cells administered to non-survivors during sepsis in comparison to survivors was previously noted in an equally small retrospective study [10]. In addition, the transfusion of stored erythrocytes was found to increase mortality or risk of multi-organ failure in posttraumatic or postsurgical patients [12-16]. Hence, our results are consistent with the concept that prolonged storage duration may exert an adverse effect on red blood cell quality. However, the small sample size in the present study does not allow conclusions with regard to potential effects on overall mortality.

The potential mechanisms underlying a more favorable clinical course in patients transfused with fresh erythrocytes remain obscure. Altered microcirculatory blood flow leading to impaired oxygen delivery and/or utilization is thought to participate in the development of organ dysfunction in sepsis. However, no increase in direct oxygen consumption or improvements in global indices of tissue oxygenation such as $\mathrm{pH}$, base excess, or plasma lactate concentrations could be previously observed in septic or critically ill patients $[4,5]$. In concordance with these results, the present study failed to reveal any differences in base excess and plasma lactate levels between septic patients treated with fresh or stored erythrocytes. It seems, therefore, that the transfusion of ex vivo-stored erythrocytes does not necessarily lead to a deterioration of tissue oxygen utilization. This may reflect the fact that disturbances in oxygen utilization in septic shock are primarily located in the mitochondria [1], and, consequently, the effects of red blood cell transfusion are limited.
Apart from impaired tissue oxygen delivery, enhanced inflammatory response and/or endothelial dysfunction might additionally contribute to the increased mortality in septic patients receiving stored erythrocytes [21]. Transfusion of packed red blood cells has been noted to provoke systemic inflammatory response attributable to the accumulation of cytokines in the supernatant of stored erythrocytes [22-24]. Moreover, administration of stored erythrocytes was shown to exacerbate the inflammatory response produced by subclinical endotoxemia in a murine model of transfusion [25]. In the present study, we monitored both inflammation and endothelial activation in septic patients receiving fresh or stored erythrocytes, but failed to detect any differences between both groups. Hence, our results argue against the notion that either inflammatory response or endothelial activation contribute to the less favorable clinical course in patients receiving stored red blood cells.

Several limitations of the present study have to be acknowledged. First, due to the low number of anemic patients with septic shock and need for ventilatory support transferred to our intensive care unit, and due to the high mortality in this group, only a small number of individuals matching the inclusion criteria could be included in the study, which limits its power and precludes statistical analysis of confounding factors. Second, as only the effects of single transfusions were examined in this study, the potentially deleterious effects of a more frequent administration of stored red blood cells may have been overlooked. Third, large intra-individual variability of parameters reflecting systemic inflammation and endothelial activation might have masked more subtle differences between groups receiving stored or fresh erythrocytes. Because of these limitations, the present findings do not provide unequivocal evidence supporting beneficial effects of fresh red blood cell transfusion in patients with septic shock. Nevertheless, they warrant further larger randomized studies with primary and secondary endpoints to confirm or refute these potential effects.

\section{Acknowledgement}

The most helpful technical assistance of Ms. Melanie Perreira is gratefully acknowledged. This study was supported by internal resources of the Medical Faculty at the University of Münster to W.S and J.-R. N.

\section{Disclosure Statement}

The authors declare no conflict of interests. 


\section{References}

1 Fink MP: Bench-to-bedside review: cytopathic hypoxia. Crit Care 2002;6:491-499.

2 Dellinger RP, Levy MM, Carlet JM, Bion J, Parker MM, Jaeschke R, Reinhart K, Angus DC, BrunBuisson C, Beale R, Calandra T, Dhainaut JF, Gerlach H, Harvey M, Marini JJ, Marshall J, Ranieri M Ramsay G, Sevransky J, Thompson BT, Townsend S, Vender JS, Zimmerman JL, Vincent JL: Surviving Sepsis Campaign: international guidelines for management of severe sepsis and septic shock: 2008. Crit Care Med 2008;36:296-327.

3 Rivers E, Nguyen B, Havstad S, Ressler J, Muzzin A, Knoblich B, Peterson E, Tomlanovich M; Early Goal-Directed Therapy Collaborative Group: Early goal-directed therapy in the treatment of severe sepsis and septic shock. N Eng J Med 2001; 345:1368-1377.

$\checkmark 4$ Fernandes CJ Jr, Akamine N, De Marco FV, De Souza JA, Lagudis S, Knobel E: Red blood cell transfusion does not increase oxygen consumption in critically ill septic patients. Crit Care 2001;5:362367.

5 Marik PE, Sibbald WJ: Effect of stored-blood transfusion on oxygen delivery in patients with sepsis. JAMA 1993;269:3024-3029.

6 Sakr Y, Chierego M, Piagnerelli M, Verdant C, Dubois MJ, Koch M, Creteur J, Gullo A, Vincent JL, De Backer D: Microvascular response to red blood cell transfusion in patients with severe sepsis. Crit Care Med 2007;35:1639-1644.

7 Hébert PC, Wells G, Blajchman MA, Marshall J, Martin C, Pagliarello G, Tweeddale M, Schweitzer I, Yetisir E: A multicenter, randomized, controlled clinical trial of transfusion requirements in critical care. Transfusion Requirements in Critical Care Investigators, Canadian Critical Care Trials Group. N Eng J Med 1999;340:409-417.

$>8$ Ho J, Sibbald WJ, Chin-Yee IH: Effects of storage on efficacy of red cell transfusion: when is it not safe? Crir Care Med 2003;31:687-697.
Raat NJ, Verhoeven AJ, Mik EG, Gouwerok CW, Verhaar R, Goedhart PT, de Korte D, Ince C: The effect of storage time of human red cells on intestinal microcirculatory oxygenation in a rat isovolemic exchange model. Crit Care Med 2005;33:39-45.

10 Purdy FR, Tweeddale MG, Merrick PM: Association of mortality with age of blood transfused in septic ICU patients. Can J Anaesth 1997;44:12561261.

11 Koch CG, Li L, Sessler DI, Figueroa P, Hoeltge GA, Mihaljevic T, Blackstone EH: Duration of red-cell storage and complications after cardiac surgery. N Eng J Med 2008;358:1229-1239.

12 Ranucci M, Carlucci C, Isgrò G, Boncilli A, De Benedetti D, De la Torre T, Brozzi S, Frigiola A: Duration of red blood cell storage and outcomes in pediatric cardiac surgery: an association found for pump prime blood. Crit Care 2009;13:R207.

13 Leal-Noval SR, Jara-López I, García-Garmendia JL, Marín-Niebla A, Herruzo-Avilés A, CamachoLaraña P, Loscertales J: Influence of erythrocyte concentrate storage time on postsurgical morbidity in cardiac surgery patients. Anesthesiology 2003; 98:815-822.

14 Mynster T, Nielsen HJ; Danish RANX05 Colorectal Cancer Study Group: Storage time of transfused blood and disease recurrence after colorectal cancer surgery. Dis Colon Rectum 2001;44:955-964.

15 Offner PJ, Moore EE, Biffl WL, Johnson JL, Silliman CC: Increased rate of infection associated with transfusion of old blood after severe injury. Arch Surg 2002;137:711-716.

16 Taylor RW, O’Brien J, Trottier SJ, Manganaro L, Cytron M, Lesko MF, Arnzen K, Cappadoro C, Fu M, Plisco MS, Sadaka FG, Veremakis C: Red blood cell transfusions and nosocomial infections in critically ill patients. Crit Care Med 2006;34: 2302-2308
7 Walsh TS, McArdle F, McLellan SA, Maciver C, Maginnis M, Prescott RJ, McClelland DB: Does the storage time of transfused red blood cells influence regional or global indexes of tissue oxygenation in anemic critically ill patients? Crit Care Med 2004;32:364-371.

18 Dessertaine G, Hammer L, Chenais F, Rémy J, Schwebel C, Tabah A, Ara-Somohano C, Bonadona A, Hamidfar-Roy R, Barnoud D, Timsit JF: Does red blood cell storage time still influence ICU survival? Transfus Clin Biol 2008;15:154-159.

19 Kneyber MC, Gazendam RP, Markhorst DG, Plötz FB: Length of storage of red blood cells does not affect outcome in critically ill children. Intensive Care Med 2009;35:179-80.

20 Wan L, Naka T, Uchino S, Bellomo R: A pilot study of pulse contour cardiac output monitoring in patients with septic shock. Crit Care Resusc 2005;7: 165.

21 Ho J, Sibbald WJ, Chin-Yee IH: Effects of storage on efficacy of red cell transfusion: when is it not safe? Crit Care Med 2003:31(12 suppl):S687-S697.

22 Fransen E, Maessen J, Dentener M, Senden N, Buurman W: Impact of blood transfusions on inflammatory mediator release in patients undergoing cardiac surgery. Chest 1999;116:1233-1239.

23 Sparrow RL, Patton KA: Supernatant from stored red blood cell primes inflammatory cells: influence of prestorage white cell reduction. Transfusion 2004;44:722-730.

24 Wadhwa M, Seghatchian MJ, Dilger P, Contreras M, Thorpe R: Cytokine accumulation in stored red cell concentrates: effect of buffy-coat removal and leucoreduction. Transfus Sci 2000;23:7-16.

25 Hod EA, Zhang N, Sokol SA, Wojczyk BS, Francis RO, Ansaldi D, Francis KP, Della-Latta P, Whittier S, Sheth S, Hendrickson JE, Zimring JC, Brittenham GM, Spitalnik SL: Transfusion of red blood cells after prolonged storage produces harmful effects that are mediated by iron and inflammation. Blood 2010;115:4284-4292. 